\title{
FOOD POISONING ABILITY OF STAPHYLOCOCCUS AUREUS ISOLATED FROM MEAT PRODUCTS AND POULTRY MEAT
}

\author{
MOHAMED KARMI \\ Department of Food Hygiene, Faculty of Veterinary Medicine, Aswan University, 81528 Aswan, Egypt
}

Received: 27 May 2019; Accepted: 20 June 2019

\begin{abstract}
A total of 200 samples including 100 samples from fresh and frozen chicken meat (breast and thigh muscles) and 100 samples from meat products (Minced meat, Burger, Luncheon and Sausages) were collected from Aswan markets. All samples were bacteriologically and biochemically examined for isolation and identification of Staph aureus, PCR detection of sea, seb, sec genes specific for staphylococcal enterotoxins (SEs). Prevalence of Staph aureus in fresh chicken meat were $72 \%$ and $68 \%$ in breast and thigh muscles, respectively, while in frozen chicken meat were $52 \%$ and $40 \%$ in breast and thigh muscles, respectively. Prevalence of Staph aureus in meat products were $20 \%, 24 \%, 0 \%, 0 \%$ in minced meat, luncheon, burger and sausage, respectively. Genetic investigation of toxigenic genes showed presence of sea and sec in all positive isolates and absence of seb gene. Ability of Staph aureus to cause food poisoning to the consumer depends mainly on the presence or absence of enterotoxins-forming genes in the isolated bacterium and PCR is a sensitive and reliable method for detection of virulent strains of Staph aureus in meat and poultry.
\end{abstract}

Key words: Staphylococcus aureus, meat, poultry, products, prevalence, enterotoxins, PCR.

\section{INTRODUCTION}

Staphylococcus aureus (Staph aureus) is a gram positive bacterium secret enterotoxins which responsible for food poisoning in human through consumption of meat and poultry (Genigeorgis, 1989, Wieneke et al., 1993), which containing enough dose of pre-prepared toxins (Dinges et al., 2000, Le Loir et al., 2003). The most characteristic feature of staphylococcal food poisoning (SFP) is the rapid onset through 3-8 hours as well as nausea, vomiting, abdominal cramps and rarely diarrhea and lasts for 12 days. Sever course can occur in children and elderly who get infection through consumption of processed meat and dairy products. The implicated foods are prepared and handled in unhygienic manner and stored in higher temperatures. Degree of contamination and the environmental conditions may favor the growth and multiplication of the microorganism and subsequently the formation of large amounts of enterotoxins (Downs and Ito, 2001). Staph aureus is the second food borne pathogen causing food poisoning in the world after Salmonella (Atanassova et al., 2001). S. aureus conforms a large proportions of nosocomial infections especially methicillin - resistant Staph aureus (MRSA) which

Corresponding author: Dr. Mohamed Karmi

E-mail address: karmy99@ yahoo.com

Present address: Department of Food Hygiene, Faculty of Veterinary Medicine, Aswan University, 81528 Aswan, Egypt resistant to several antibiotics such as quinolones (Ortega et al., 2010). Staph aureus normally inhabit about $20 \%$ of people and $60 \%$ are carriers (Kluytmans et al., 1997). It is found normally in the nasal cavity of most people which causing infection in people with lowered immunity especially in carrier persons while non-carrier persons can get infection through consumption of contaminated foods (Von Eiff et al., 2001). Enterotoxin type A is the most common cause of food poisoning everywhere beside other types (Argudin et al., 2010). Staphylococcal enterotoxins are resistant to heat, acidity and proteolytic enzymes and preserve activity after processing and digestion, it is active in low micrograms (Schantz et al., 1965). Staph aureus is a very serious pathogen in food poisoning and in hospital infections and characterized by production of virulent heat stable toxins which are responsible for toxic shock like syndrome and food poisoning as well as induction of $\mathrm{T}$ cells proliferation as superantigen (Harris et al., 1993, Martin et al., 2003, Kérouanton et al., 2007). Hemolysin, thermonuclease, lipases and hyaluronidase are virulence factors responsible for the pathogensis of Staph aureus (Sandel and McKillip, 2004, Normanno et al., 2007, Kuroda et al., 2007). Enterotoxins type A, D and B are the most risky and notable ones in food poisoning. Type A is more common then type B which used as inhalational bioweopon (Ler et al., 2006). Type D is the second common cause of food poisoning and in a very small dose (Bergdoll et al., 1981). Type E has the ability to 
cause food poisoning while type $\mathrm{F}$ causes toxic shock syndrome (Morris et al., 1972). Type G, H and I are not common in food poisoning although they implicated in outbreak in Taiwan (Chen et al., 2004). Type $\mathrm{H}$ also was isolated as a causative agent of massive food poisoning from reconstituted milk in Osaka, Japan in 2000 (Ikeda et al., 2005). Therefore, this work was planned to study the prevalence of Staph aureus in meat products and poultry meat samples as well as PCR detection of staphylococcal enterotoxins (SEs)-forming genes in isolated bacteria,

\section{MATERIALS AND METHODS}

\section{Samples}

A total of 200 samples including 100 samples from chicken meat; 50 fresh and 50 frozen (breast and thigh muscles) and 100 samples from meat products (minced meat, burger, luncheon and sausages) were collected from Aswan markets. Sampling box containing ice pads was used for carrying the samples from market to laboratory maintaining low temperature. Samples were preserved in sterile polyethylene bags in the refrigerator. Twenty five grams of each chicken meat or meat product sample were aseptically transferred to sterile stomacher bag, homogenized by using Stomacher ${ }^{\circledR} 400$ Circulator (Seward Ltd., UK) and mixed in $225 \mathrm{ml}$ Buffered Peptone Water (BPW).

\section{Isolation and Identification}

The mixture samples were incubated at $37{ }^{\circ} \mathrm{C}$ for 18 24 hours. Pre-incubated samples $(0.1 \mathrm{ml})$ in BPW were spread on the surface of Baird-Parker agar (BPA) medium supplemented with Egg-Yolk Tellurite Emulsion and Mannitol salt Agar (MSA) (Oxoid Limited, Hampshire, England), a selective media for Staph aureus and incubated at $37{ }^{\circ} \mathrm{C}$ for 24-48 hours. Black colonies surrounded by whitish halo zone formation on BPA and yellow colonies on MSA were considered presumptive Staph aureus, confirmed with the help of Gram's staining, coagulase, catalase and other biochemical tests (Szabo, 2000, Bennett and Lancette, 2001).

\section{Genetic Detection}

DNA extraction was carried out by using boiling method; DNA was prepared by the whole-cell procedure. Each DNA template was prepared by using approximately half a loopful of culture transferred to $1 \mathrm{ml}$ of TE buffer $(\mathrm{pH} 8)$ and mixed in suspension. The resulting suspension was heated at $100^{\circ} \mathrm{C}$ for 10 minutes and centrifuged at $13000 \mathrm{rpm}$ for 5 minutes. A five $\mu l$ aliquot was directly used as a template for PCR amplification (LawrynowiczPaciorek et al., 2007). Primer sequences were used as forward and reverse for sea, seb and sec genes used for identification of toxin genes (Table 1). Multiplex PCR amplification of toxigenic genes was carried out, each reaction consists of $2.5 \mu 1$ of $10 \mathrm{x}$ buffer, $10 \mu 1$ master mix, $0.5 \mu \mathrm{l}$ each primer, $3 \mu \mathrm{l}$ DNA template and nuclease free water till $25 \mu 1$ volume (Rahimi, 2013). Thermacycler (Eppendorf, Germany) was used with initial denaturation step at $94^{\circ} \mathrm{C}$ for 5 minutes followed by 30 cycles (denaturation at $94^{\circ} \mathrm{C}$ for 0.5 minute, annealing at $59^{\circ} \mathrm{C}$ for 0.5 minute and extension at $72^{\circ} \mathrm{C}$ for 0.5 minute for toxin genes) (Akbar and Anal, 2013), ending with final extension at $72^{\circ} \mathrm{C}$ for 10 minutes. Amplified products were analyzed by $1.5 \%$ agarose gel electrophoresis stained with ethidium bromide and visualized on UV transilluminator (Martineau et al., 1998, Rall et al., 2008, Zouharova and Rysanek, 2008).

\section{RESULTS}

Overall prevalence of pathogenic coagulase-positive Staph aureus was $70 \%, 46 \%$ and $11 \%$ in fresh chicken meat, frozen chicken meat and meat products samples, respectively. Prevalence of Staph aureus in breast and thigh muscles of fresh chicken was $72 \%$ and $68 \%$ while in breast and thigh muscles of frozen chicken was $52 \%$ and $40 \%$, respectively (Table 2). In meat products, prevalence of Staph aureus were $20 \%$ and $24 \%$ in minced meat and luncheon, respectively, while burger and sausage were free from contamination by Staph aureus. Genetic investigation of toxigenic genes showed presence of sea gene in $51 \%$ of fresh chicken meat, $35 \%$ of frozen chicken meat, $100 \%$ of minced meat and luncheon positive Staph aureus isolates while seb gene was failed to be detected in examined samples while sec gene was found in $37 \%$ of fresh chicken meat, $17 \%$ of frozen chicken meat and $100 \%$ of minced meat and luncheon positive Staph aureus isolated (Table 3).

Table 1: Primer sequences and expected size of PCR amplified gene targets of Staph aureus (Gayathri and Prakash, 2014).

\begin{tabular}{|c|c|c|c|}
\hline Gene & Primer & Oligonucleotide sequence $\left(5^{\prime} \rightarrow 3^{\prime}\right)$ & Product size(bp) \\
\hline \multirow{2}{*}{ sea } & sea $(F)$ & TTGCAGGGAACAGCTTTAGG & \multirow[t]{2}{*}{247} \\
\hline & sea $(\mathrm{R})$ & TACCACCCGCACATTGATAA & \\
\hline \multirow{2}{*}{ seb } & seb $(\mathrm{F})$ & CGCATCAAACTGACAAACGA & \multirow[t]{2}{*}{243} \\
\hline & $\operatorname{seb}(\mathrm{R})$ & CCGTTTCATAAGGCGAGTTG & \\
\hline \multirow{2}{*}{$\sec$} & $\sec (\mathrm{F})$ & TCCGTTGGCTTTTCACTTTT & \multirow[t]{2}{*}{163} \\
\hline & $\sec (\mathrm{R})$ & GTTAAATCGGGTGGTGCAAT & \\
\hline
\end{tabular}


Table 2: Prevalence of pathogenic Staph aureus in fresh chicken meat, frozen chicken meat and meat products.

\begin{tabular}{|c|c|c|c|c|}
\hline \multicolumn{2}{|c|}{ Type of sample } & $\begin{array}{c}\text { Number } \\
\text { examined }\end{array}$ & Positive number & Samples Percentage \\
\hline \multirow{3}{*}{ Fresh chicken meat } & Breast & 25 & 18 & 72 \\
\hline & Thigh & 25 & 17 & 68 \\
\hline & Total & 50 & 35 & 70 \\
\hline \multirow{3}{*}{ Frozen chicken meat } & Breast & 25 & 13 & 52 \\
\hline & Thigh & 25 & 10 & 40 \\
\hline & Total & 50 & 23 & 46 \\
\hline \multirow{5}{*}{ Meat products } & Minced & 25 & 5 & 20 \\
\hline & Luncheon & 25 & 6 & 24 \\
\hline & Burger & 25 & 0 & 0 \\
\hline & Sausage & 25 & 0 & 0 \\
\hline & Total & 100 & 11 & 11 \\
\hline
\end{tabular}

Table 3: Prevalence of toxigenic genes (sea, seb, sec) in Staph aureus isolated from fresh chicken meat, frozen chicken meat and meat products.

\begin{tabular}{ccccccccc}
\hline \multirow{2}{*}{ Sample examined } & \multirow{2}{*}{ Number } & \multicolumn{3}{c}{ sea } & \multicolumn{3}{c}{ seb } & \multicolumn{3}{c}{ sec } \\
\cline { 3 - 9 } & & $+\mathrm{ve}$ & $\%$ & $+\mathrm{ve}$ & $\%$ & +ve & $\%$ \\
\hline Fresh chicken meat & 35 & 18 & 51 & 0 & 0 & 13 & 37 \\
\hline Frozen chicken meat & 23 & 8 & 35 & 0 & 0 & 4 & 17 \\
\hline Minced meat & 5 & 5 & 100 & 0 & 0 & 5 & 100 \\
\hline Luncheon & 6 & 6 & 100 & 0 & 0 & 6 & 100 \\
\hline Total & 69 & 37 & 53.6 & 0 & 0 & 28 & 40.6 \\
\hline
\end{tabular}

\section{DISCUSSION}

In this study, the overall prevalence of pathogenic coagulase-positive Staph aureus was $70 \%, 46 \%$ and $11 \%$ in fresh chicken meat, frozen chicken meat and meat products samples, respectively. It is noticed that highest rate of contamination was in fresh chicken meat $(70 \%)$ then in frozen meat chicken $(46 \%)$ and lower rates in meat products $(20 \%$ in minced meat and $24 \%$ in luncheon). Comparison of these results with results of other authors revealed that overall prevalence of Staph aureus in chicken meat $(70 \%$, 46\%) was in agreement with results such as: $85.71 \%$ (Capita et al., 2001), 68.53\% (Islam et al., 2014), 67.5\% (Gundogan et al., 2005), 57.1\% (Kitai et al., 2005), 50.98\% (Rasheed, 2011), 41\% (Waters et al., 2011 ) and higher than other results of $25 \%$ (Bhargava et al., 2011), 18.18\% (Akbar and Anal, 2013), 17.8\% (Hanson et al., 2011), 12.8\% (Heo et al., 2008), 7.8\% (Lin et al., 2009). Prevalence of Staph aureus in meat products (20\% in minced meat and $24 \%$ in luncheon) was in agreement with results such as: $20.5 \%$ (Bhargava et al., 2011), lower than results such as: 63\% (Jackson et al., 2013), 45.6\% (van Loo et al., 2007), 50\% (Abdalrahman et al., 2015), 37\% (Waters et al., 2011) and higher than results such as: $10 \%$ (Heo et al., 2008), 6.9\% (Hanson et al., 2011), 6.1\% (Gutierrez et al., 2012). Results revealed that $51 \%$ of fresh chicken meat, $35 \%$ of frozen chicken meat, $100 \%$ of minced meat and luncheon having enterotoxin A-producing gene (sea) which is responsible for occurrence of staphylococcal food poisoning in consumers and considered the main cause of emetic symptoms. About $37 \%$ of fresh chicken, $17 \%$ of frozen chicken and $100 \%$ of minced meat and luncheon having enterotoxin $\mathrm{C}$ - producing gene $(\mathrm{sec}$ ) while enterotoxin B-producing gene (seb) was absent in all samples. These results indicated that isolated strains of Staph aureus having ability to produce one or more than one enterotoxins which responsible for food poisoning in consumers and appearance of their symptoms.

Contamination of meat by Staph aureus, which may due to unsanitary conditions during processing and preparation, conform a high risk to the consumers (Gundogan et al., 2005). Certain steps in poultry slaughter such as scalding, defeathering, washing and chilling may increase the incidence of contamination of poultry meat by $S$. aureus (Hansson, 2001, Spescha et al., 2006). Large proportions of meat and poultry get contaminated by Staph aureus which reached 37$77 \%$ and about $52 \%$ of the isolates are resistant to multiple antibiotics (Waters et al., 2011). Staph aureus produce several exotoxins such as toxic shock syndrome toxins, coagulase, hemolysin, exfoliative toxin and about fifteen types of enterotoxins (Mehrotra et al., 2000). Shock syndrome toxin and enterotoxins type A and B are more dangerous toxins and superantigens (Gunaydin et al., 2011). The higher 
contamination of retail meat by Staph aureus is the higher potential of MRSA transfer to the consumers (Shukla et al., 2010). It is found that incidence of Staph aureus in poultry meat $(65.8 \%)$ was higher than that of beef (20-25\%) or pork (26-29\%) (Shimizu et al., 1991, Jiang et al., 2001). Poultry meat get contaminated by Staph aureus through two main sources; the first one is by poultry types which found in the nasal cavity and intestines of the birds and contaminate the meat during slaughter steps and the second one is the human types which found on the skin and hands of workers who handle and prepare the poultry meat (Shimizu et al., 1986, Saitoh et al., 1994, Arai et al., 2004). The food poisoning ability and the pathogenicity of Staph aureus are attributed mainly to formation of exo- and endotoxins (Sandel and McKillip, 2004).

About fifteen enterotoxins produced by Staph aureus (Atichou et al., 2004), types A, B, C, D and E are the more common and considered the main cause of food poisoning while the other types such as $\mathrm{G}$ and O may play minor role in food poisoning (Jay et al., 2005). The role of the novel discovered types of enterotoxins in the food poisoning or other affections is still not clear enough and need more research. The use of innovative genetic characterization of enterotoxin forming genes may be useful in the study of these toxins. The majority of Staph aureus strains isolated from food produce enterotoxins type A, C and D (Rahimi, 2013). The enterotoxins are heat stable and resist denaturation to still intact in the food and subsequently induce food poisoning. Also, the major problem is the occurrence of multidrug resistant strains of Staph aureus which causing antibiotic-associated diarrhea in the hospitals (Pinchuk, et al., 2010).

\section{CONCLUSION}

Meat products and poultry meat products are considered important sources for pathogenic Staph aureus which get contaminated either from animal origin or from human during processing and preparation. All Staph aureus isolates contained one or more enterotoxin-forming genes which give the bacteria the ability to cause food poisoning to the consumers. Enterotoxin type $\mathrm{A}$ and type $\mathrm{C}$ were considered the main enterotoxins and may be responsible for occurrence of food poisoning outbreaks.

\section{AUTHORS' CONTRIBUTIONS}

Author performs collection, preparation, processing, and analysis of samples, isolation of bacteria, data acquisition, writing, preparation and revision of manuscript.

\section{ACKNOWLEDGEMENTS}

I thank Faculty of Veterinary Medicine, Aswan University for technical support.

\section{REFERENCES}

Abdalrahman, L.S.; Wells, H. and Fakhr, M.K. (2015): Staphylococcus aureus is more prevalent in retail beef livers than in pork and other beef cuts. Pathogens, 4: 182-198.

Akbar, A. and Anal, A.K. (2013): Prevalence and antibiogram study of salmonella and Staphylococcus aureus in poultry meat. Asian Pac J Trop Biomed., 3(2): 163-168.

Arai, T.; Okada, S. and Shimizu, A. (2004): Staphylococcus aureus contamination in a poultry-processing plant and biological properties of isolates. J. Jpn. Vet. Med. Assoc. 57: 460-464.

Argudín, M.A.; Mendoza, M.C. and Rodicio, M.R. (2010): Food poisoning and Staphylococcus aureus enterotoxins. Toxins (Basel), 2(7): 1751-1773.

Atanassova, V.; Meindl, A. and Ring, C. (2001): Prevalence of Staphylococcus aureus and staphylococcal enterotoxins in raw pork and uncooked smoked ham--a comparison of classical culturing detection and RFLP-PCR. Int J Food Microbiol., 68 (1-2): 105-113.

Atichou, M.; Henkens, R.; Sultana, A.; Ulrich, R. and Ibrahim, M. (2004): Detection of Staphylococcus aureus enterotoxin A and B genes with PCR-EIA and a hand-held electrochemical sensor. Mol Cell Probes 18: 373-377.

Bennett, R.W. and Lancette, G.A. (2001): Staphylococcus aureus, Chapter 12, rev. Jan. 2001. In FDA Bacteriological analytical manual, 8th ed., Rev. A. AOAC International, Gaithersburg, MD.

Bergdoll, M.S.; Crass, B.A.; Reiser, R.F.; Robbins, R.N. and Davis, J.P. (1981): A new staphylococcal enterotoxin, enterotoxin $\mathrm{F}$, associated with toxic-shock-syndrome Staphylococcus aureus isolates. Lancet., 1: 1017-1021.

Bhargava, K.; Wang, X.; Donabedian, S.; Zervos, M.; da Rocha, L. and Zhang, Y. (2011): Methicillin-resistant Staphylococcus aureus in retail meat, Detroit, Michigan, USA. Emerg Infect Dis., 17(6): 1135-1137.

Capita, R.; Alonso-Calleja, C.; Moreno, B. and García-Fernández, C. (2001): Assessment of Baird-Parker agar as screening test for determination of Staphylococcus aureus in poultry meat. J Microbiology 39(4): 321-325.

Chen, T.R.; Chiou, C.S. and Tsen, H.Y. (2004): Use of novel PCR primers specific to the genes of staphylococcal enterotoxin G, H, I for the 
survey of Staphylococcus aureus strains isolated from food-poisoning cases and food samples in Taiwan. Int. J. Food Microbiol., 92: 189-197.

Dinges, M.M.; Orwin, P.M. and Schlievert, P.M. (2000): Exotoxins of Staphylococcus aureus. Clin. Microbiol. Rev., 13: 16-34.

Downs, M. and Ito, H.P. (2001): Susceptibility of staphylococcus to heat treatment and sanitizing agents. J. vet. Sci, 8(2): 151-154.

Gayathri, D. and Prakash, M.S. (2014): Evaluation of developed multiplex PCR technique of staphylococcus aureus for specificity and its efficiency on food samples. J. Biol. Engg. Res. \& Rev., 1(2): 13-19.

Genigeorgis, C.A. (1989): Present state of knowledge on staphylococcal intoxication. Int. J. Food Microbiol. 9: 327-360.

Gunaydin, B.; Aslantas, O. and Demir, C. (2011): Detection of superantigenic toxin genes in Staphylococcus aureus strains from subclinical bovine mastitis. Trop. Anim. Health Prod., 43, 1633-1637.

Gundogan, N.; Citak, S.; Yucel, N. and Devren, A. (2005): A note on the incidence and antibiotic resistance of Staphylococcus aureus isolated from meat and chicken samples. Meat Science, 69(4): 807-810.

Gutiérrez, D.; Delgado, S.; Daniel Vazquez-Sanchez, D.; Martinez, B.; Cabo, M.L.; Rodriguez, A.; Herrera, J.J. and Garcia, P. (2012): Incidence of Staphylococcus aureus and analysis of associated bacterial communities on food industry surfaces. Applied and Environmental Microbiology, 78(24): 8547-8554.

Hanson, B.M.; Dressler, A.E.; Harper, A.L.; Scheibel, R.P.; Wardyn, S.E.; Roberts, L.K.; Kroeger, J.S. and Smith, T.C. (2011): Prevalence of Staphylococcus aureus and methicillin-resistant Staphylococcus aureus (MRSA) on retail meat in Iowa. J Infection and Public Health, 4(4): 169-174.

Hansson, I.B. (2001): Microbiological meat quality in high- and low capacity slaughterhouses in Sweden. J. Food Prot. 64: 820-825.

Harris, T.O.; Grossman, D.; Kappler, J.W.; Marrack, P.; Rich, R.R. and Betley, M.J. (1993): Lack of complete correlation between emetic and Tcell-stimulatory activities of staphylococcal enterotoxins. Infect. Immun., 61: 3175-3183.

Heo, H.J.; Ku, B.K.; Bae, D.H.; Park, C.K. and Lee, Y.J. (2008): Antimicrobial resistance of Staphylococcus aureus isolated from domestic and imported raw meat in Korea. Korean J Vet Res, 48(1): 75-81.

Ikeda, T.; Tamate, N.; Yamaguchi, K. and Makino, S. (2005): Mass outbreak of food poisoning disease caused by small amounts of staphylococcal enterotoxins A and H. Appl. Environ. Microbiol., 71:2793-2795.
Islam, N.N.; Akter, M.; Farzana, Z.; Bin Kader, A.; Uddin, I.; Siddiki, Z. and Kamaruddin, K.M. (2014): Detection of Staphylococcus aureus in frozen chicken rinse through bacteriological and Nuc gene specific PCR methods and their drug resistance patterns in southern Chittagong, Bangladesh. Research J Microbiology, 9(5): 251-264.

Jackson, C.R.; Davis, J.A. and Barrett, J.B. (2013): Prevalence and characterization of methicillinresistant Staphylococcus aureus isolates from retail meat and humans in Georgia. J. Clin Microbiol., 51(4): 1199-1207.

Jay, M.J.; Loessner, J.M. and Golden, A.D. (2005): Staphylococcal gastroenteritis. In: Modern Food Microbiology. 7th edition. Springer Science, New York, pp 545-560.

Jiang, C.M.; Liu, P.H.; Ding, J.P.; Liu, X.G.; Hu, D.L. and Shinagawa, K. (2001): Incidence and pollution of enterotoxigenic Staphylococcus aureus in milk, meat and fish in China. Jpn. J. Food Microbiol. 18: 43-47.

Kérouanton, A.; Hennekinne, J.A.; Letertre, C.; Petit, L.; Chesneau, O.; Brisabois, A. and Buyser, M.L.D. (2007): Characterization of Staphylococcus aureus strains associated with food poisoning outbreaks in France. Int. J. Food Microbiol., 115:369-375.

Kitai, S.1.; Shimizu, A.; Kawano, J.; Sato, E.; Nakano, $\quad$ C.; Kitagawa, H.; Fujio, $\quad K$; Matsumura, K.; Yasuda, R. and Inamoto, $T$. (2005): Prevalence and characterization of Staphylococcus aureus and enterotoxigenic Staphylococcus aureus in retail raw chicken meat throughout Japan. J Vet Med Sci., 67(3): 269-74.

Kluytmans, J.; van Belkum, A. and Verbrugh, $H$. (1997): Nasal carriage of Staphylococcus aureus: epidemiology, underlying mechanisms, and associated risks. Clin. Microbiol. Rev., 10: 505-520.

Kuroda, M.; Nagasaki, S.; Ito, R. and Ohta, T. (2007): Sesquiterpene farnesol as a competitive inhibitor of lipase activity of Staphylococcus aureus. FEMS Microbiol. Lett., 273: 28-34.

Lawrynowicz-Paciorek, M.; Kochman, M.; Piekarska, K.; Grochowska, A. and Windyga, B. (2007): The distribution of enterotoxin and enterotoxin-like genes in Staphylococcus aureus strains isolated from nasal carriers and food samples. Int J Food Microbiol., 117 (3): 319-23.

Le Loir, Y.; Baron, F. and Gautier, M. (2003): Staphylococcus aureus and food poisoning. Genet. Mol. Res., 2: 63-76.

Ler, S.G.; Lee, F.K. and Gopalakrishnakone, P. (2006): Trends in detection of warfare agents. detection methods for ricin, staphylococcal enterotoxin B and T-2 Toxin. J. Chromatogr. A., 1133: 1-12. 
Lin, J.; Yeh, K.; Liu, H. and Lin, J. (2009): International association for food protection research note Staphylococcus aureus isolated from pork and chicken carcasses in Taiwan: prevalence and antimicrobial susceptibility. Journal of Food Protection, 72 (3): 608-611.

Martin, M.C.; Gonzalez-Hevia, M.A. and Mendoza, M.C. (2003): Usefulness of a two-step PCR procedure for detection and identification of enterotoxigenic staphylococci of bacterial isolates and food samples. Food Microbiol., 20: 605-610.

Martineau, Mellon, M.; Benbrook, C.; Benbrook, K.L. and Carolina, K.L. (1998): Identification and isolation of staphylococcus species by simplified and recent methods. J. clin. Microbiol, 43: 421-426.

Mehrotra, M.; Wang, G. and Johnson, W.M. (2000): Multiplex PCR for detection of genes for Staphylococcu aureus enterotoxins, exfoliative toxins, toxic shock syndrome toxin 1, and methicillin resistance. J. Clin. Microbiol., 38, 1032-1035.

Morris, C.A.; Conway, H.D. and Everall, P.H. (1972): Food poisoning due to staphylococcal enterotoxin E. Lancet., 2: 1375-1376.

Normanno, G.; Salandra, G.L.; Dambrosio, A.; Quaglia, N.C.; Corrente, M.; Parisi, A.; Santagada, G.; Firinu, A.; Crisetti, E. and Celano, G.V. (2007): Occurrence, characterization and antimicrobial resistance of enterotoxigenic Staphylococcus aureus isolated from meat and dairy products. Int. J. Food Microbiol., 115: 290-296.

Ortega, E.; Abriouel, H.; Lucas, R. and Gálvez, A. (2010): Multiple roles of Staphylococcus aureus enterotoxins: pathogenicity, superantigenic activity, and correlation to antibiotic resistance. Toxins (Basel), 2 (8): 2117-2131.

Pinchuk, I.V.; Beswick, E.J. and Reyes, V.E. (2010): Staphylococcal enterotoxins. Toxins, 2, 21772197.

Rahimi, E. (2013): Enterotoxigenicity of Staphylococcus aureus isolated from traditional and commercial dairy products marketed in Iran. Braz J Microbiol., 44(2): 393-399.

Rall, V.L.; Vieira, F.P.; Rall, R.; Vieitis, R.L.; Fernandes, A.J.; Candeias, J.M.; Cardoso, K.F. and Araújo, J.P. (2008): PCR detection of staphylococcal enterotoxin genes in Staphylococcus aureus strains isolated from raw and pasteurized milk. Vet Microbiol., 132(3-4): 408-13.

Rasheed, B.Y. (2011): Isolation and identification of bacteria causing arthritis in chickens. Iraqi Journal of Veterinary Sciences, 25(2): 93-95.

Saitoh, Y.; Shimizu, A.; Yagi, M.; Adachi, T.; Kawano, J.; Hikami, Y.; Gohda, M. and Sukigara, S. (1994): Characteristics of
Staphylococcus aureus isolated from healthy and diseased chickens. Sci. Rept. Fac. Agr. Kobe Univ. 21: 1-9.

Sandel, M. and McKillip, J. (2004): Virulence and recovery of Staphylococcus aureus relevant to the food using improvement on traditional approaches. Food Control 15: 5-10.

Schantz, E.J.; Roessler, W.G.; Wagman, J.; Spero, L.; Dunnery, D.A. and Bergdoll, M.S. (1965): Purification of staphylococcal enterotoxin B. Biochemistry, 4 (6): 1011-1016

Shimizu, A.; Kawano, J. and Kimura, S. (1986): Biotyping of coagulase-positive Staphylococcus aureus and Staphylococcus intermedius strains isolated from various animals in Japan. Jpn. J. Vet. Sci. 48: 12271235 .

Shimizu, A.; Ozaki, J.; Kawano, J. and Kimura, S. (1991): Isolation and characterization of Staphylococcus aureus from raw fish and meat. Jpn. J. Food Microbiol. 8: 135-141.

Shukla, S.K.; Karow, M.E.; Brady, J.M.; Stemper, M.E.; Kislow, J.; Moore, N.; Wroblewski, K.; Chyou, P.H.; Warshauer, D.M.; Reed, K.D.; Lynfield, R. and Schwan, W.R. (2010): Virulence genes and genotypic associations in nasal carriage, community-associated methicillin-susceptible and methicillinresistant USA400 Staphylococcus aureus isolates. J. Clin. Microbiol., 48(10): 35823592.

Spescha, C.; Stephan, R. and Zweifel, C. (2006): Microbiological contamination of pig carcasses at different stages of slaughter in two European Union-approved abattoirs. J. Food Prot. 69:2568-2575.

Szabo, R.A. (2000): Enumeration of Staphylococcus aureus in foods, MFHPB-21. Compendium of analytical methods. Health Protection Branch, Health Canada. Ottawa, Ontario.

Van Loo, I.H.M.; Diederen, B.M.W.; Savelkoul, P.H.M.; Woudenberg, J.H.C.; Roosendaal, R.; Van Belkum, A.; Toom, N.L.; Verhulst, C.; Van Keulen, P.H.J. and Kluytmans, J.A.J.W. (2007): Methicillin resistant Staphylococcus aureus in meat products, the Netherlands. Emerg Infect Dis., 13(11): 1753-1755.

Von Eiff, E.C.; Becker, K.; Machka, K.; Stammer, H. and Peters, G. (2001): Nasal carriage as a source of Staphylococcus aureus bacteremia study group. N. Engl. J. Med., 344: 11-16.

Waters, A.E.; Contente-Cuomo, T.; Buchhagen, J.; Liu, C.M.; Watson, L.; Pearce, K.; Foster, J.T.; Bowers, J.; Driebe, E.M.; Engelthaler, D.M.; Keim, P.S. and Price, L.B. (2011): Multidrug resistant Staphylococcus aureus in US meat and poultry. Clinical Infectious Diseases, 52(10): 1-4.

Wieneke, A.A.; Roberts, D. and Gilbert, R.J. (1993): Staphylococcal food poisoning in the United 
Kingdom, 1969-90. Epidemiol. Infect. 110: 519-531.

Zouharova, M. and Rysanek, D. (2008): Multiplex PCR and RPLA identification of
Staphylococcus aureus enterotoxigenic strains from bulk tank milk. Zoonoses Public Health. 55(6): 313-319.

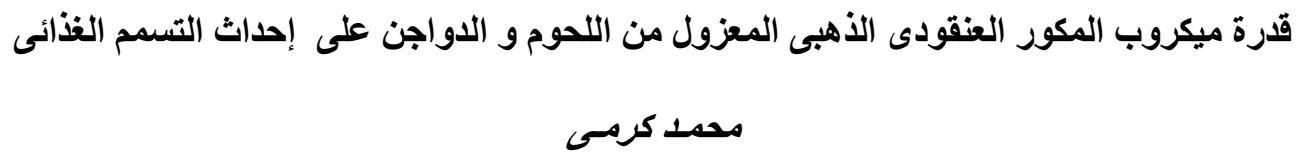

E-mail: karmy99@yahoo.com_Assiut Univers ity web-site: www.aun.edu.eg

تم إجر اء هذا البحث لدر اسة معدل انتشار ميكروب المكور العنقودى الذهبى فى منتجات اللحوم ولحوم الدواجن وللكثف على الجينات

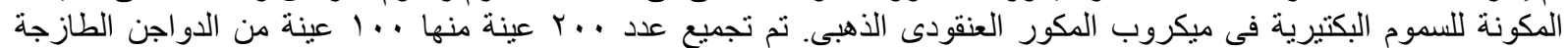

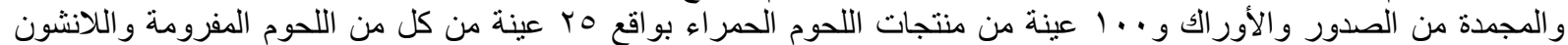

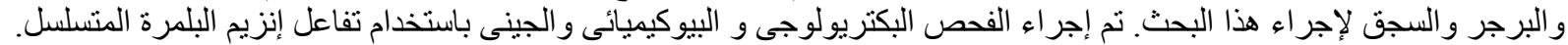

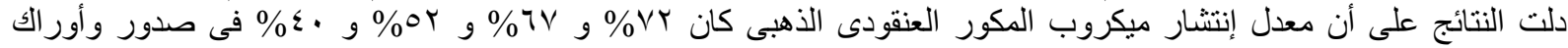

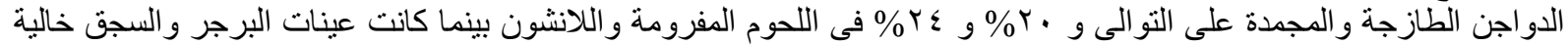

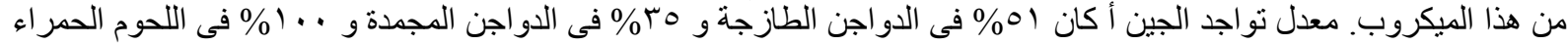

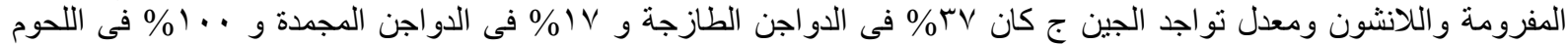

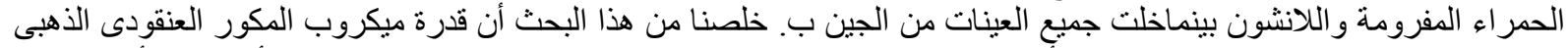

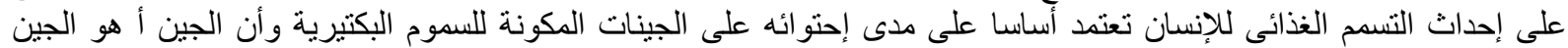

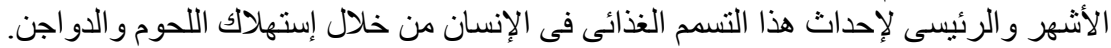

